\title{
GEOCRYOLOGICAL ZONES OF ANTARCTICA
}

\section{(Abstract only)}

by

\section{B. I. Vtyurin}

(c/o Dr V. M. Kotlyakov, Institute of Geography, Academy of Sciences of the U.S.S.R., Staromonetny per. 29, Moscow 109017, U.S.S.R.)

\section{ABSTRACT}

Criteria for the determination of geocryological zones are: (1) distribution of permafrost, (2) the mean annual temperature of permafrost, (3) thickness of the active layer, (4) types of ground ice and ice content of permafrost, (5) regularities of cryogenic structure, (6) cryogenic phenomena, and (7) types of cryogenic relief.

Interpretation of the available data allows us to delineate the following geocryological zones in the Antarctic: (1) sub-Antarctic islands, (2) coasta1continental, and (3) intercontinental. The brief general geocryological characteristic of these zones is given in the paper.

The sub-Antarctic island zone features discontinuous and continuous permafrost. The mean annual temperature of the permafrost is near $0^{\circ} \mathrm{C}$ and the maximum thickness is several tens of metres. The seasonal thawed zone has a thickness of 0.4 to $1.2 \mathrm{~m}$. There are visible ice inclusions and very small ice forms in the permafrost and seasonal frost. Frost action causes frost sorting, hill-slope forms, and thermokarst. I ce-wedges are not found in the sub-Antarctic zone.
The coastal-continental zone has continuous permafrost. The mean annual temperature of the permafrost there is $-1^{\circ} \mathrm{C}$ in the Antarctic Peninsula and up to -5 to $-7^{\circ} \mathrm{C}$ in East Antarctica. Maximum thickness of the permafrost is over $100 \mathrm{~m}$ and the active layer is 0.3 to $1 \mathrm{~m}$. The ground ice is mainly pore ice but in some places there is buried glacier ice in moraine. Frost action, frost sorting, creep, nivation, and pre-glacial slope forms are developed in the coastalcontinental zone.

The intercontinental zone consists of continuous permafrost only. The mean annual temperature of the permafrost there is $-10^{\circ} \mathrm{C}$ or lower. Thickness of this permafrost is several hundreds of metres and of the active layer is 0.1 to $0.5 \mathrm{~m}$. The ice content is low with only small ice forms. The cryogenic structure of the permafrost is the same as the coastal-continental zone. Because alternate freezing and thawing is infrequent in the intercontinental zone all cryogenic processes are less rapid than in the other zones. Thermokarst is not found there and in general the intercontinental zone is not as well studied as the two other zones.

\section{GLACIER FLUCTUATIONS IN GEORGE VI SOUND AREA,}

\section{WEST ANTARCTICA}

\section{(Abstract only)}

\author{
by \\ C. M. Clapperton and D. E. Sugden \\ (Department of Geography, University of Aberdeen, Aberdeen AB9 2UF, Scotland)
}

\section{ABSTRACT}

George VI Sound lies between Alexander Island and the Antarctic Peninsula and is over $20 \mathrm{~km}$ wide and $500 \mathrm{~km}$ long. At present an ice shelf fills the sound and is nourished largely by ice from the Antarctic Peninsula which flows across the sound to ground against the coast of Alexander I I land. I ce-free areas, comprising small nunataks and larger massifs, fringe both sides of the sound and contain evidence of the former glacial history of the area. This paper describes the field evidence in detail and uses geomorphological and sedimentary analyses to put forward a relative glacial chronology, constrained by two absolute dates.

The chronology distinguishes:

(1) a maximum state during which all ice-free areas were submerged by ice flowing into George VI Sound from both the Antarctic Peninsula and Alexander I sland and thence along the sound as an ice stream. This occurred in the late Wisconsin and followed an interstadial or interglacial when George VI Sound was free of an ice shelf.

(2) a valley-based stadial during overall deglaciation represented by pronounced marginal moraines on Alexander Island.

(3) deglaciation to a stage where there was less landbased ice on Alexander I sland than today. At this stage isostatic recovery was incomplete, relative sealevel was higher, and George VI Ice Shelf penetrated further into embayments on Alexander Island than at present.

(4) probable disappearance of George VI Ice Shelf by $6.5{ }^{14} \mathrm{C}$ ka BP

(5) neoglacial readvance of 1 ocal glaciers on Alexander Island to form three closely spaced terminal moraines and the growth of a new George VI Ice Shelf which was again more extensive than at present.

(6) subsequent oscillations of both smaller Alexander Island glaciers and George VI Ice Shelf probably during the Little Ice Age. These fluctuations are similar to those in other sub-Antarctic Islands in the Scotia Sea and also in southern Chile. 